\title{
An Aesthetic Visualization of Ritual Ordering among the Yoruba Drummer: A Medium of Life Celebration
}

\author{
Olusegun Adebolu Oladosu \\ Obafemi Awolowo University, Nigeria \\ Olusegunoladosu1@gmail.com \\ adeb12345@yahoo.com
}

\begin{abstract}
The gatherings among Yoruba people depicting religion, social or political values are usually staged with drumming. At the center of this art are the professional drummers with the cult identity of àyàn. The display, ordering and aesthetic of drumming are usually often come with some rituals during passages of life which are frequently unknown to the non-initiates. The study underscores the significant of ritual that are connected to birth, puberty, middle stage and death which are very important to life stages among the Yoruba people. It highlights the role of ritual rites in the profession of drumming in a selected town in Yoruba land. The paper use in-depth interview, participant observation, archival materials and ethnographic methods to generate data needed for its analysis. This paper through phenomenological analysis will process the data collected.
\end{abstract}

\section{Introduction}

Drumming is an essential profession worldwide. The profession, however, has its own significance defined by culture and beliefs from one region to another. In Africa, a drummer cannot be identified without its drum because the drum is a material symbol, an identified object that gives drummer a status. The physical manifestation of drum coupled with the human action of the drummer underline the attributes attached to the drumming profession. This profession may differ in practice from one region to the other due to cultural and religious influences. Among the Ile-Ife, Oshogbo, Ibadan and Oyo Yoruba people of southwestern, Nigeria, the profession has a dynamic 
aesthetic ritual ordering which place it within theological context of passages of life that involves rite and ritual which may not be culturally bounded to other continents or areas.

It is evident that "drums are an essential symbol of art and culture, not only in Yorubaland but also in Nigeria and Africa in general. It is connected to entertainment, language and culture." This views tallies with position that "one of the things that have come out of culture is the drum." Within the trio of entertainment, language and culture, Olorunyomi affirms that drum could perform three major functions namely: mode, messenger and message. ${ }^{3}$ These three functions foreground drum in social entertainment and ritual aesthetic. For a drum to perform all three functions, the efforts of the drummer cannot be underemphasized.

A drummer, according to Bankole et al (1975), is a composer, a poet, a historian, a philosopher, a psychologist, and a repository of religious knowledge. ${ }^{4}$ These underlined features of a drummer allow him to be relevant in the usage of the drum in the three stages of life transformation among the Yoruba, which are birth, puberty, and death. It follows therefore that the drummer in Yoruba tradition must also be ritually transformed within these three stages of life in carrying out their professional activities. These stages are embedded with different categories of poetic records that are located in historical facts of the people. The records refer to the people by the level of philosophical, psychological, and religious manifestation adapted through their custom and culture. The drummers in this sense serve as the repository of knowledge that manifests these by the virtue of their indigenous and traditional qualities and talents in which they were brought up with. To follow these, the drummer must by order of the tradition learn and follow the act of religious procedure attached to the deity of the Yoruba drum known as àyà $n$ through which they are made sacred to fulfil the cultural objectives. Within this procedure is the recognition of the ritual ordering which not the less serves as the platform for other necessary practices of a Yoruba drummer. The discussion of this paper through ethnographic methods, in-depth interview and

1 . A. Lasisi, "Set to Beat his New Drum", in Nigeria Punch Newspaper, Wednesday, May 2, 2012, p. 51

2 . Y. Ogunyemi, "Drums of Africa: Sound, Vision and Politics." Paper delivered at the Symposium hosted by the Institute of African Studies (IAS), University of Ibadan and Ayan Agalu Soungobi Foundation (AASF) on Thursday 23rd August, 2012.

3 S. Olorunyomi, "The Drum as Medium, Message and Messenger" Paper delivered at the Symposium hosted by the Institute of African Studies (IAS), University of Ibadan and Ayan Agalu Soungobi Foundation (AASF) on Thursday 23rd August, 2012.

4 A. Bankole (et al), "The Yoruba Master Drummer" in African Arts, UCLA, James S. Coleman Studies Centre, Vol. 8, No 2, 1975 p. 51. 
phenomenological analysis, will explore the medium through which Yoruba drummers are therefore ritualised for these functions.

\section{Functions of Ritual Ordering}

It is quite reasonable to look at the functions of ritual ordering as exemplified by Arbuckle, the varieties in the ordering will be emphasized in line with this paper. ${ }^{5}$ Firstly, when rituals are done in a right direction, it relieves anxiety. This establishes good rapport between the society and individual. It thus alleviates possible complications or elements of tension that may mar relationships. The more there is ritual ordering, the less in the development of chaos or contradiction in social relationship. This ideal situation is applicable to the ritual as practiced by the Yoruba drummer because complication in the ladder of life passages of any drummer is guided and corrected through ritual.

Secondly, the symbolic representation in ritual ordering tends towards caution. This caution refrains people from behaving arbitrarily. In this wise, ritual ordering is used in constraining behavior because people must adapt feeling and sense of awe towards certain actions. This is a true figure that must be created in the mind of any Yoruba drummer. Thirdly, ritual ordering is used to articulate boundaries. This is significant in symbolic articulation and affirmation of material items, place and times. This is necessary because such symbolic emphasis raises boundaries in the action and reaction of the people towards themselves and their community. It thus instills consciousness that will make people relate rationally within their social and spiritual context.

Fourthly, ritual ordering is used for incorporating contradictions. The usage of symbols in rituals is significant to representation of ideas that are beyond comprehension, especially sacred thoughts that have spiritual connotation. It is noticeable that most symbols exemplified inner emotions and thus create a bridge between physical and spiritual or secular and sacred. These two polar worlds are separated by gap. This gap serves as contradiction in several cases. Taking for example, stages of movement in transformational passages of birth, puberty, marriage and death are gaps which involve identification and reconciliation of profanity and sacredness in Yoruba custom. The identification and reconciliation must be done with ritual rites, undermining this may create contradiction which probably results to crisis. To prevent the contradiction, necessary ritual procedure must be followed.

5 G.A. Arbuckle, Culture, Inculturation and Theologians: A Postmodern Critiques, Minnesota: Liturgical Press, 2010, pp.84-90. 


\section{Analysis of Ordering Functions of Ritual}

There is need to make a semantic clarification in the analysis of the ordering function which formed the fulcrum of this study. In the social context of human development, it is observed by Arbuckle ${ }^{6}$ that cultures serve as processes of ritualizing life. According to Arbuckle, the processes involved are the ordering functions and transformational quality of the ritual. These rituals are fundamental and serve to be a momentary way of how existing order of human development within social context are put in shape without chaos or conflicts. The platform of social context identifies rules for how things are done and failure to observe such rules may serve as a challenge to human development. The position of these rules is considered in its entirety to the symbolic ritual aspects which articulate meaning. The essence of its ordering is to reinforce meaning in the right direction as this will bring transformation into human or individual cultural experience. So, the rituals that are ordered in the right direction bring a reform of cultural changes which eventually assist a person in any transformational stages.

The challenge of resolving the universal issues ranging from birth, puberty, marriage and death are very germane to Yoruba drummer because these issues stand to manifest with the formation of their carrier at any level and at the same time serve as an interdiction of achieving the goal of their destiny. Reason for this has to do with the sacred order of the attachment of Yoruba drumming profession to àyàn, the òrị̀a deity of the profession which reinforced their spirituality. This deity must be ritually placated in a symbolic way that involves material items, places and times. This gesture will allow the adherents to be well directed and motivated in their various endeavor. So, if rituals connected to this deity are well ordered, then it poses a good omen to the adherents and the initiates because it gives them values.

\section{The Synopsis of Ritual Manifestation}

Ritual is defined as a series of actions that are carried out in the same way, especially as part of a religious ceremony ${ }^{7}$. This ritual ceremony involves some practices that are done almost the same way at different period. Yoruba explanation for this is "ilànà ìsìn" or "ọnà ìsìn tí ó hàn lóde" (forms of religious practices that can be explained). ${ }^{8}$ Ritual as a form of liturgy is explained by

6 G.A. Arbuckle, Culture, Inculturation and Theologians: A Postmodern Critiques, 2010, p.81.

7 E. J. Sowande, S. Crowther, Yoruba Dictionary, Oxford: Oxford University Press, 1937.

8 Ibid. 
Awolalu and Dopamu as a prescribed practice for public worship. ${ }^{9}$ This practice entails communication and communion with a deity within the context of worship. It is noted in this sense that most of the worship and festival go with a particular type of drum that is made sacred for a peculiar ritual.

Ritual, according to John Mbiti, is known to be a method of carrying out religious actions or ceremony. ${ }^{10}$ It is also a means of communicating something of religious significance, through word, symbol and action. Mbiti's assertion indicates that Africans celebrate life and by doing this they celebrate their religion by dancing, singing and acting. A visible demonstration of these activities occurs in ritual and festivals. Parrinder and Mbiti in some regards agreed with each other in the aspects of ritual. ${ }^{11}$ It is highlighted by both of them that ritual could take communal or personal form. Personal ritual is considered as the rites that surround the principal events in the lives of individuals while the communal ritual shows the relationship of religion to the structure of the society. Meanwhile, Alward Shorter in his observation of Marja-Lisa Swantz compendium of ritual analysis through criterion of social experience shows that communal rituals could be communitarian if a community is involved in its performance. ${ }^{12}$ In recent time among the Africans, he made it clear that this type of rituals are otherwise dwindling into family rituals. This assertion is important for this paper because the drumming profession among the Yoruba is only peculiar to family groups that are engaged in the profession. Such family have their own template of ritual rite which keeps them intact in the affairs of their day to day professional activities.

This submission shows that rituals can generate a sense of certainty and familiarity. It can also provide continuity and unity among those who perform or attend them. In turn, people find a degree of identity through this common observance and experience. Through the ritual action and word, people are able to exercise a certain amount of control over the invisible world and forces of nature. In this way, humans feel themselves to be not just a passive creature in the universe, but creative agents. For the purpose of ritual, human beings use almost everything at their disposal to communicate their actions and words. They use oral formulas including the drum in terms of invocation and prayers to connect to both the vertical and horizontal networks of mystical powers necessary for ritual purposes in different forms and occasions. The

9 J. O. Awolalu, P.A. Dopamu, West African Traditional Religion, Ibadan: Macmillan, 2005 p. 128.

10 J. S. Mbiti, Introduction to African Religion, Norfolk: Heinemann, 1991, pp. 131-143.

11 E. G. Parrinder, African Traditional Religion, London: Sheldon, 1975, pp. 79-90.

12 A. Shorter, African Culture: An Overview, Nairobi: Pauline Publications Africa, 2001, p.62. 
contents of ritual as described above and as also linked to the drum will help us to know why a drummer in Yoruba tradition must be ritualized.

\section{Phases of Ritual Rites among the Yoruba Drummers}

The social or religious activities which display the acts of the usages of drum normally explain the level of ritual practices that must be involved. Be as it may, the acts of its use must be performed by an expertise known as the drummer. The drummer in Yoruba cosmology is referred to as àyàn. For any Yoruba drummer to have the tendency of performing these acts successfully, they must be ritualized.

Looking at rituals in African cosmology, John Mbiti shows that ritual is an arm of religious practices of the Africans. ${ }^{13}$ The fundamental aspects of this religious life are the acts of worship which are found through rituals, ceremonies and festivals. This thus shows that through the acts of worship, Africans love to celebrate life. Celebration in this regard identifies particular events in the life of the individual and the community. The events are: birth, naming, marriage, initiation, funeral, harvest and praying. These events are considered to be informed by one ritual or the other. Many of the rituals are either family based or community based and could show a great deal of religious conducts which are transmitted from one generation to the other.

Mbiti's explanation attests to the fact that a ritual in African setting serves as a platform through which religious actions or ceremonies are carried out. It is a means of communicating religious significance through word, symbol or action. The description of Mbiti thus infers that a ritual is a concept that concerns the life of an individual in passages of life. This identification in Mbiti's assertion portrays a ritual as "a means of generating sense of certainty and familiarity. It also provides continuity among those who perform or attend them. It also gives people a degree of identity through the common observance and experience." 14

The Yoruba drummers with the identification noted above have a form of ritualized identity which connects them to the religion of àyan and which allows them to exhibit a ritual performance in festivals. In this sense, it shows that, there is a particular rite which establishes their performances in rituals that form religious action. This rite establishes their relationship and improves the doctrine of their faith.

The rite from this dimension of faith doctrine is situated within personal rituals as considered by Parrinder. ${ }^{15} \mathrm{He}$ explains that a personal ritual

13 J.S. Mbiti, Introduction to African Religion, Norfolk: Heinemann, 1991, p. 131.

14 J.S. Mbiti, Introduction to African Religion, p.13.

15 E.G. Parrinder, African Traditional Religion, London: Sheldon Press, 1975, p. 90. 
involves rites that surround the principal events in the lives of individuals. To him, traditional rites of the people of Africa are described as marks of stages in the lives of the common people. Arnold Van Gennep refers to this as rites of passage ${ }^{16}$. The stages involved are birth, puberty, marriage and death which are the points where rites and rituals must be observed. These stages serve as different occasions through which Yoruba drummers must be ritualized in their profession. They also serve as an emblem for religion of àyàn to which they are adherents.

Ajayi indicates that drumming among the Yoruba people is a family profession. ${ }^{17}$ These families are often referred to collectively as the clan of àyà $n .{ }^{18}$ Àyàn is the Yoruba drum deity whose name the members of these families incorporate into their own. Such names include Àyànsọlá, Àyànwàlé and Àyànwèmí. The family of Àyàn is closely aligned to the details of the worship of Àyàn and this gives them a sense of religious commitment as a traditional family that has an origin linked with the deity. This linkage influences the family life from birth till death. The sense of belonging is seen from different stages of life as traditional ritual rites are done to mark their acceptance in the family.

Every drummer that plays different kinds of drums is considered to have a link with Àyàn lineage. Though, the system of playing the drum is also open to outside talents, but the so called outside talents are dislodged from the cultural and religious knowledge that would be picked up by the bonafide members of the family. The reason for this has to do with several rituals which sacralise the stages of the members and which outsiders cannot be connected with. The rituals allow the drummer from the house of àyà $n$ to emphasize matters of traditional importance, such as how to please the gods and his elders, how to communicate more to his listeners than the message his drum speaks. $^{19}$

The cultural and religious relevance of an àyà $n$ (drummer) are, therefore, connected to three phases. The phases are the birth, the developmental stages vis-à-vis marriage and training and the death. These stages have ritual types that order and transform the social life of the families. The rites involved go with a lot of social drama through which actions are symbolised and psychic

16 A.V. Gennep, The Rite of Passage: A Classic Study of Cultural Celebration, London: Routledge and Paul Kegan Ltd, 1960, pp. 8-15.

17 B. Ajayi, "The Talking Drum”, in Nike S. Lawal et al (ed.). Understanding Yoruba Life and Culture, Trenton and Eritrea: African World Press,2004, p. 584.

18 A. Bankole (et al), “The Yoruba Master Drummer” in African Arts, UCLA, James S. Coleman Studies Centre, Vol. 8, No 2, p. 49.

19 A. Bankole, p. 50. 
forces like ancestors are linked. This linkage gives the Yoruba drummers the access to ritual functions in most festivals that they are meant to involve in.

Rite of Passage, according to Awolalu and Dapamu, connote meaningful transformations in the life cycle. The cycle of life is seen within the birth of a child and also ends at deaths. The transition from birth, puberty, marriage and death are thus important turning points. The passages of life are, therefore, marked with peculiar religious ceremonies and rites. In the view of Awolalu and Dopamu, such religious rites vary from one ethnic group to another and the significance of the passages varies from clan to clan, or family to family of the same ethnic group. ${ }^{20}$

In the light of the Àyàn family, the birth rite is not only taken to be a joyous moment but it emphasises how to commit the new baby into the hands of the ancestors. The baby will be dedicated to Àyàn as the divinity that will protect the child in the world. During the period, the child is presented for ritual naming after nine days, in the case of a male, and seven days in the case of a female. It is very important that the newly born child in Ayàn family is given bath with a borrowed sponge and soap in order for the baby not be feeling shy when begging for money from people when he is matured enough to parade the trade of drumming. This is an important ritual that must be done.

What is important to the baby during this time is not only the name that will be given but the rituals which identify drumming profession for the child. This tradition is called yíya ìlù (giving the child his or her own drum). With this, the baby is symbolically located within the traditional family of the Àyàn and carries the prefix name of Àyàn with other names like Àyànsọlá, Àyányemí and Àyánwùmí.

The ceremony is performed by the elders of the Àyàn group in the family. Materials like free range games (ẹran igbé), otíkà (wine made from beans), èkọ (solid pap), kolanut, bitter kola (orógbó), palm oil, water and the drum ensemble that the family is connected with like bàtá, dùndún, ìpèsè, igbin or any others are presented. The officials will use the materials to bless the baby and initiate him or her into the cult of Àyàn. The prayer to be offered here are in connection with the materials presented that symbolize old age, undisturbed life and warding off of evil during the passage of life. If this rite is not done for such a baby, it shows that he or she will not have a say in the family and this may affect the life of the baby, as time goes on. This is one way of ritualizing the drummer from birth. ${ }^{21}$

20 J.O. Awolalu \& P.A. Dopamu, West African Traditional Religion, Ibadan: Macmillan, 2005, p.196.

21 Oral Interview granted by J. Adereti, Baale Onilu of Ife, at Lokore Street, Ile-Ife on $7 / 01 / 2013$. 
The training period is another phase through which the passage of puberty and middle life are symbolically represented and celebrated. The training is meant for the households of the drummers and the training involves a traditional education that takes so much time in life time. The children within the household become an apprentice and would have to face the challenge of the training with courage. The ceremony that would later establish the trainee as a recognized drummer within the family is not always elaborate, and there are no fixed charges but the commemoration would have to be done with the worship of Àyàn (the deity of the drum). The worship is done with otíkà (wine made from beans), ẹkọ (solid pap) and ẹran igbẹ (free range game). During the worship, the drum set of the ensemble meant for the family must be available for the rites.

This rite situates the son within the family as a potential candidate within the tribe of Ayàn to assume the status of a master drummer when he is grown up after the exit of the adult master drummer in the family. This training, therefore, equips and gives the drummers the competence required in the matters of traditional importance, cultural experiences and the art of technical skill in the area of vocal inclination such as the àásán, ògèdè and ọfọ̀ (incantations). This medium of training allows the trainee to know how to evoke and handle psychic forces of tremendous potencies. ${ }^{22}$ This stage of ritual established that there would be drummers as bonafide practitioners within the profession and it thus identified them as members of the cult of àyàn. However, those who possess the talents of drumming but are not from the linage of Àyàn are not identified with this cult system.

The rite entrenched in the death rite of any Àyàn is all encompassing with traditional representation of the culture involved in the life cycle of the tribe. This stage is as important as that of the birth rite. The importance shows a magnificent signifier of rituals which identify and separate every worshipper of Àyàn from every other outsider that does not identify with the cult of àyàn. The ritual in this stage is meant generally for the descendants of every àyàn lineage. Emphasis made by Adereti as regards this particular stage of life shows that the stage is highly portrayed with sanctity and sacredness. ${ }^{23}$ Death stage among the Àyàn is an important scenario through which practices of ritual activities are displayed. The lineage of Àyàn sees death as a transition from the physical world to the spirit world. The deceased is, therefore, considered to be making a journey from this earth to another place considered to be the ancestral world of their family. Every Àyàn must as a matter of

22 A. Bankole, p. 50.

23 Oral Interview granted by J. Adereti, Baale Onilu of Ife, at Lokore Street, Ile-Ife on $7 / 01 / 2013$. He is 62 years old. 
necessity be given the ritual ceremony. The ceremony is considered to be orò àyàn (àyàn ritual).

Adereti identified the fact that the ritual involved in this stage takes prominent significance in the life style of the cultural identity of the Ayàn group. ${ }^{24}$ If this is not done or if there is any backlog of such rituals in such àyàn group, this backlog may cause bad omen to the affected family. The practices of this ritual involve religious ceremonies which include ritual dance that is extremely ordered by songs and drums. The process is highly symbolic due to the materials involved and the level at which the event is celebrated. The materials involved are listed as follows: ọsọọọ̣tu, òrí (shea-butter), epo pupa (palm oil) ẹní àtẹ́rin (mat), obi (kola nut), akika, abệrẹ (needle), ẹyẹlé (pigeon), àkùkọ adiyẹ (cork), ẹfọ́ wộrọọ̣wọ́ (a local spinach), ệọ́ àtètèdáyé (a local spinach), èfọ́ òdúdú (local spinach), ìgbín (snail), èkuru (white beans meal), eja gbígbe (dried cat fish), òbúkọ (he goat), white cloth, several food and schnapps.

The above materials are figuratively presented and used as symbol of the ritual in ushering the deceased to the world of his or her ancestors. In the process, the sacrificial materials like goat, pigeon, chicken and the dried cat fish are offered for sacrifice. The blood of the living animals mentioned must be shed on the burial ground of the deceased. In this process, palm oil will be poured intermittently during the course of the prayers. During the prayers, the drum that is identified with the deceased from birth would be brought out and the membrane will be torn into pieces. This shows that he or she is bid farewell into the spirit world. The remaining palm oil later would be used as medicine for the healing of any indisposed member of the family. The oil serves as ẹ̀rọ (antidote).

The ritual also involved decoration of any member of the cult that is of the same height and size with the deceased with the ẹni àtẹrin (mat). The man will come out in form of masquerade during the ritual process. Every son and daughter of the deceased must put on the cloth of their father or mother which he or she wore during his or her life time. This is done to give the deceased the last respect. Apart from this, all other participants involved must wear white clothes during the ritual process. As this is done, the procession of the participants will follow to every part of the community which the deceased lived. The important place to be visited during this occasion is the market place. The masquerade must lead the procession.

The practice involved in this ritual process is known to be orò àbàtà (mud ritual). This ritual involves splitting of mud during the procession on any

24 Oral Interview granted by J. Adereti, Baale Onilu of Ife, at Lokore Street, Ile-Ife on $7 / 01 / 2013$. 
participant involved in the ritual. The reason for wearing the white cloth is glaringly done as a means of showing the effects of the mud. This action symbolically portrays the fact that man must surely return back to the mud. The recognition of the masquerade in this procession shows the facts that the ancestors who had already departed are there to join them. The masquerade, therefore, serves as a link to the ancestors. After the return of the procession, the mat which the masquerade is decorated with will be used to cover the burial ground of the deceased and this shows a final rite.

The ritual process identified within this purview of passages of life endowed the Àyàn drummer the rights to participate in any ritual performance involved in festivals. The process shows the impression why àyàn cult seems to be recognized within the society and every other religious event. This recognition serves to be a result of the way drummers ritualise themselves within the important passages of life.

\section{Ritual of Protection}

In another dimension, there are other means through which the drummers pass through ritual processes. Sometime they learn to protect themselves against enemies within or outside their profession. Charms in form of medicine are the safe methods of ritual process which they adopt. This method allows them to use their drums to talk to their rivals or invoke the power of any of the deities especially Ògún, the god of iron. Ògún is identified with the worship of Àyàn because of his protective quality. It is believed by them that he is tough and could give courage and confidence to the master drummer. ${ }^{25}$ Bankole explains the link between Ògún and Àyàn deities through the symbol of iron strings constructed with the sacred gúdúgúdú drum. ${ }^{26}$ He notes that this is only done to the gúdúdúdú of a master drummer from the house of àyàn. In the centre of the iron piece is a sacrificial mark on which libations are made during àyàn worship. The 'gúdúgúdu' drum is known to form a typical combination at any social or ritual ceremony ${ }^{27}$. The face of the drum is covered with thick etu (deer) skin and with frequent libation on the drum and the skin, it is imbibed with spiritual potency. According to Arawande, the skin becomes a ritual material either for antidote or other purpose not disclosed ${ }^{28}$. The libations are done with kola nuts, palm wine and the blood of an animal. Prayers are then offered to Àyàn. This ritual imbibes the drummers with spiritual power against any attack whenever they are on a business errand.

25 A. Bankole, p. 54.

26 A. Bankole, p. 54.

27 B. Ajayi, “The Talking Drum”, p.582.

28 Oral Interview granted by A. Arawande (Drum maker) at 55, Obalufe Compound, Iremo, Ile-Ife on 29/05/13. He is 45years old. 
Also, it is noted that the dundún, talking drum, is sometimes inscribed with the dot of Ejì Ogbè at both ends of the membrane. Ėjì Ogbè is an Ifá verse that presents the spiritual light that is known and unknown in the universe. ${ }^{29}$ Bascom narrated that, Ėjì Ogbè is identified with figure symbol of eight shells with their mouth facing up..$^{30}$ The letters of the figure are the names of the deities or other superhuman entities associated with the figures. The recitations of the verse are as follows:

Orí ire nií dádé owó

Orùn ire nií so èjigbà ilẹkẹ

İdí rere nií fi ení ò ré sèté

Ló día fún Ara-tùmí tí șe obinrin òọsà, òoṣà là lórí

O ní òọsà tí mo bá tètè ire ni ilàrí

İwọ òọà ni mo dá

Aré òè ki i tẹ lójú ẹní là lóriß

A lucky head wears a crown of cowries

A lucky neck wears jasper beads

Lucky buttocks use a special mat as tent

Was the one who divined for "My- body- at- ease"

who was the wife of òoșà

Òòsà initiated her

She said òòsà if I use your throne,

I am unfaithful to you, òòsà,

The first born of the hill is not disgraced in the eyes of his initiator

In another version, it can also be recited as follow:

Ọkálele lébu

Àkitàn șe kẹkẹ̀gbilè

Oșùmàrè gọ ní ilé

Afiditòkun

Afệhintọ̣à

29 L. A. Fitzpatrick, African Names and Naming Practices: The Impact Slavery and European Domination had on the African Psche, Identity and Protest, Unpublished M.A. Thesis, Department of African American and African Studies, Ohio State University, 2012, p.2.

30 W. Bascom, Sixteen Cowries: Yoruba Divination from Africa to the New World, U.S.A.: The Association of American University Presses, 1980, p.5.

31 W. Bascom, Sixteen Cowries: Yoruba Divination from Africa to the New World, pp. $56-58$ 
A gbójú Ọlọrun a gaga

Dá fún Ọọ́fin

Ofọ àikús

Little by little a cobra becomes thicker

Little by little the refuse heap becomes wider

Foolish rainbow in the house

With his face to the sea

And his back to the lagoon

He looks at Olorun on high

Divined for the king

For a long life.

The analysis as given by an Ifa diviner, ${ }^{33}$ indicates its protective benefits. Sometime, the master drummer could encounter metaphysical attacks from the opponents when parading his trade. The attack could be a way of tearing or breaking the drum membrane with the influence of magic. Then, the Ejì Ogbè serves as protective measure for both the drum and the drummer. In another dimension, the Ejì Ogbè is indicated to be the king of odù within Ifá corpus. ${ }^{34}$ Its inscription on the surface of the drum gives the drummer a medium of fame and favor in his outing. It also shows the appeal which the drummer makes through Ifá to allow Àyàn the deity of the drum to take proactive measure on the outing of the drummer.

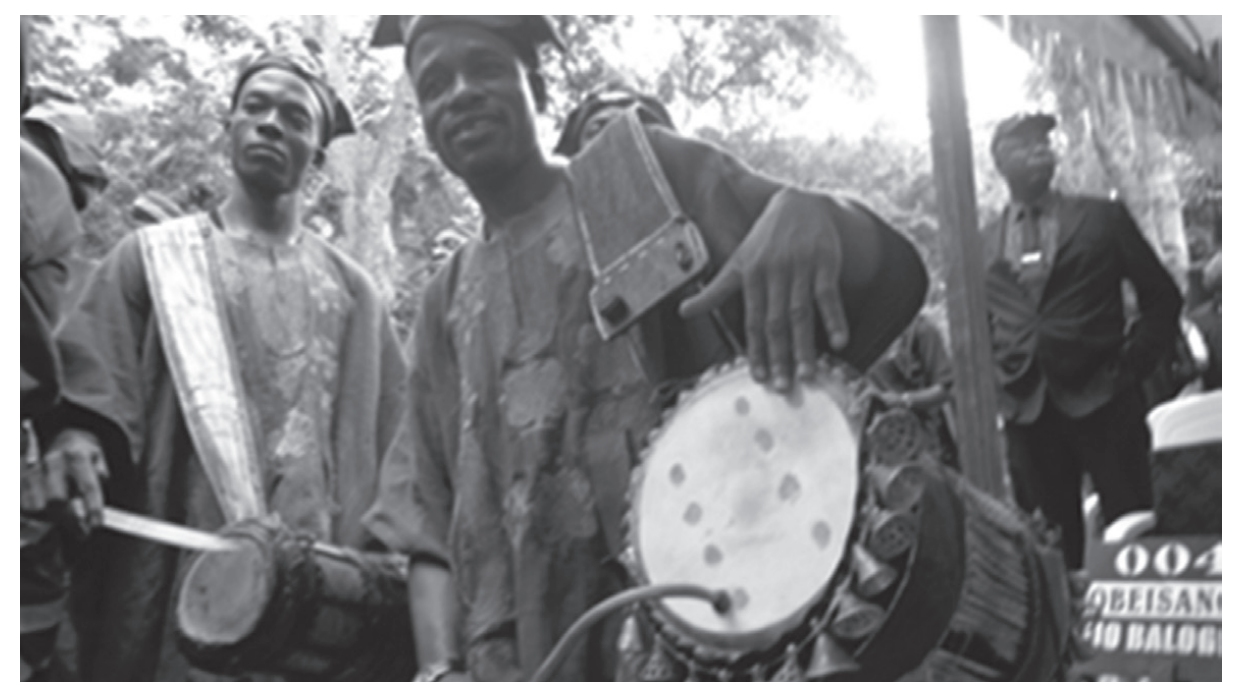

Plate 1: The inscription of Ėjì Ogbè on İyá İlù

This expresses a ritual dimension that makes the performance of the drummer effective in the acts of ritual practices in religious festival of the Yoruba people. 


\section{The Locus Standi for Ritualizing a Drummer}

The drum and the drummer in Yoruba culture are two symbolic elements connected together with the aid of ritual display. The acts of this display strengthen the relationship between the two elements and as well underlined the status of the two. This portends that a drum that is ritualized cannot just be used by anybody and likewise non-initiates among the drummers cannot participate in the nitty-gritty of the profession. Also, an initiate who may likely jettison the ethics of the family rites due to civilization have serious challenge to face as he or she climb the ladder of progress.

Jare Adereti emphasized the importance of ritual performances on drums. According to him, ritual is necessary because the deity of the drum must be worshipped. ${ }^{35}$ In doing this, the ensemble like dùndún drums will be collected together in a special occasion and the Àyàn worshippers who are also drummers will assemble for the occasion. The materials for the rite are stated to be àádùn (corn cake with oil grounded), obi (kola), eyele (pigeon), chicken, cold water, èkuru (molded beans cake) èkọ (corn meal) and ẹmu (palm wine). All these will be used for special prayers on the drum. Gúdúgúdú which is mythically recognized as the oldest of the dìndún drums is ritually recognized as the symbol of drum which libation must be poured upon.

This ritual allows the deity of the drum to be symbolically appraised and recognized. This recognition gives protection to the drummers anytime they are out to play. With this rite being performed, the drum is imbued with mystical powers which are capable of identifying any spiritual attacks on the drummers during their outing. Particularly, if they walk in the middle of the night when a contagious spiritual sacrifice is usually placed at the cross roads, the drum which has been imbibed with power through ritual is so efficacious that its power can make the sacrifice to disappear to allow the drummer to pass safely.

Also identified by Olafioye Olusegun and Alao is the issue of calendar that marked the celebration of each drum, at every yearly festival celebration. ${ }^{36}$ Spiritual rites in form of libation and sacrifice must be provided to unveil and usher in the drum. No drum must be beaten without this sacrifice. Some particular drums after being used for an important occasion must go indoors and it takes a special sacrifice to bring them out again for use. Example of this is òsírìgì, the royal drum of Ife.

35 Oral Interview granted by J. Adereti, Baale Onilu of Ife at his residence Lokore Street, Ile-Ife on 7/01/2013. He is 62 years old.

36 Oral Interview granted by I.O. Olafioye, (The P.R.O, National Association of hunters, Ife Branch) at Obaloran Compound Ile-Ife, on 28/02/13. He is 60 years old. 
During a special occasion among the hunters, Alao indicated that àgẹrẹ̣ drum must be ritualized by performing rites with materials like e yin òròrò (egg laid by a chicken within twenty-four hours), wine, corn meal (ẹkkọ) and ègúsí soup. ${ }^{37}$ The use of eyin òròrò is symbolical. The egg identifies the credence given to the voice of the chicken during its laying period. This voice serves as an important symbolic message in its communication. The use of chicken eggs in the ritual rites imbues the sound of the drum with power. Olafioye explained that if àgẹrè̀ would be used for the burial of any deceased hunter, a male goat must be sacrificed as a rite on the drum. The blood of the animal would be rubbed on the wood of the drum. This is done to appease the spirit of death not to trouble the bereaved family and the fellow hunters (àkúfà).

Generally materials like snail, cold water, iyán (pounded yam), òrí (shea-butter), and palm wine are used to consecrate ìgbìn drum while schnapps (hot drinks), four valves cola and several food items are used to consecrate bàtá drum. Schnapps, kolanut, bitter kola (orógbó), ègbo (corn porridge) are used to consecrate ìpèsè drum. Bẹnibẹ also is consecrated with palm wine, kola and ègbo (corn porridge). It thus shows that most drums are given preference with particular rites either annually, periodically or as the occasion may require.

The ritualization of drums among the Yoruba is also noted in a case where a member of the Àyàn family is having some difficulty or personal problems. This kind of rites according to Alao is referred to as re-integration rites. These rites are performed for those who are born into the lineage of Àyàn but by the virtue of civilization had forgotten their lineage custom. People with such challenges would be made to buy a she-goat. The she-goat must be with pregnancy. The she-goat will be sacrificed to appease the deity, and the skin of the foetus will be used to make a drum for the person who has the challenge. This is to establish a link between the fellow and the deity. The rite will also include other materials in accordance with the ensemble or drum applicable to the family of such person in challenge. This rite is considered as orò ilé (family ritual).

Mr. Alao Sikiru, my informant identifies family ritual among the Àyàn worshippers as a prominent rite which links them to their ancestors anywhere in the world. ${ }^{38} \mathrm{He}$ noted that, the neglects of this rite could make any of their descendants lag behind in their various endeavours. His explanation is substantiated with the story of a Christian Pastor who used to be a prompt

37 Oral interview granted by S.K. Alao, (Asipa of Lalupon) at Oyo State Cultural Centre, Mokola Ibadan on 01/03/13. He is 60 years old.

38 Oral interview granted by S.K. Alao, (Asipa of Lalupon) at Oyo State Cultural Centre, Mokola Ibadan on 01/03/13. He is 60 years old. 
observer of the àyàn tradition before becoming a pastor. He narrated that the pastor disengaged his contribution in the cult of àyàn due to his work. The pastor's achievement was later faced with serious setback as he was later advised to go and observe his traditional duties. In his repentance, his relatives thus mocked him with the following lyrics.

Enu ló kó bá a $2 x$

Pasitọ tó dolóoṣà re o

Enu ló kó bá a.

His utterance implicated him $2 \mathrm{x}$

The pastor that became idolatrous

His utterance implicated him.

\section{Conclusion}

The analysis of this paper so far clearly declared that drum and the drummer within this investigation are central to our understanding of Yoruba theological culture of ritual and rite of passages. The fact, therefore shows that ritual and its connection with drum and drummer could allow feelings related to religion and events that celebrate the tradition of the past and the present. Opinion of Arbuckle ${ }^{39}$ as regards transformative processes in line with ritual practices according to this paper, shows that a society or individual could develop or recreate itself out of struggles within rites of social drama that exist within the community.

\section{Bibliography}

Adereti J, Oral Interview, Lokore Street, Ile-Ife on 7/01/2013.

Ajayi B, "The Talking Drum", in Nike S. Lawal et al (ed) Understanding Yoruba Life and Culture, Trenton and Eritrea: African World Press, 2004, p.584.

Alao S.K, Oral interview, Oyo State Cultural Centre, Mokola Ibadan on 01/03/13.

Arawande A., Oral Interview, 55, Obalufe Compound, Iremo, Ile-Ife on 29/05/13.

Arbuckle A.G, Culture, Inculturation and Theologians: A Postmodern Critiques, Minnesota: Liturgical Press, 2010.

Awolalu J.O, DopamuP.A, West African Traditional Religion, Ibadan: Macmillan, 2005.

39 G.A. Arbuckle, Culture, Inculturation and Theologians: A Postmodern Critiques, pp.81-90. 
Bascom W., Sixteen Cowries: Yoruba Divination from Africa to the New World, U.S.A.: The Association of American University Presses, 1980.

Bankole A (et al), "The Yoruba Master Drummer" in African Arts, UCLA, James S. Coleman Studies Centre, Vol. 8, No 2, 1975.

Faniyi, A. Oral interview, Obafemi Awolowo University, Ile-Ife on 10/04/13. Fitzpatrick L.A., "African Names and Naming Practices: The Impact Slavery and European Domination had on the African Psche, Identity and Protest," Unpublished M.A. Thesis, Department of African American and African Studies, Ohio State University, 2012.

Gennep A.V., The Rite of Passage: A Classic Study of Cultural Celebration, London: Routledge and Paul Kegan Ltd, 1960.

Lasisi, A. "Set to Beat his New Drum", in Nigeria Punch Newspaper, Wednesday, May 2, 2012.

Mbiti J.S., Introduction to African Religion, Norfolk: Heinemann, 1991.

Ogunyemi Y., Drums of Africa: Sound, Vision and Politics. A Symposium by the Institute of African Studies (IAS), University of Ibadan and Ayan Agalu Soungobi Foundation (AASF), Thursday 23rd August, 2012.

Olafioye I.O., Oral Interview, Obaloran Compound Ile-Ife, on 28/02/13.

Olorunyomi, S., "The Drum as Medium, Message and Messenger" in Drums of Africa: Sound, Vision and Politics. A Symposium by the Institute of African Studies (IAS), University of Ibadan and Ayan Agalu Soungobi Foundation (AASF), Thursday 23rd August, 2012

Parrinder E.G, African Traditional Religion, London: Sheldon, 1975.

Shorter A, African Culture: An Overview, Kenya: Pauline Publications Africa, 2001.

Sowande E.J, S. Crowther, Yoruba Dictionary, Oxford: Oxford University Press, 1937 